\title{
APPLICATION OF ${ }^{239,240} \mathrm{Pu},{ }^{137} \mathrm{Cs}$ AND HEAVY METALS FOR DATING OF RIVER SEDIMENTS
}

\author{
DARIUSZ CISZEWSKI ${ }^{\mathbf{1}}$ and EDYTA LOKAS ${ }^{\mathbf{2}}$ \\ ${ }^{I}$ AGH-University of Sciences and Technology, 30-059 Krakow, Mickiewicza St. 30, Poland \\ ${ }^{2}$ Institute of Nuclear Physics Polish Academy of Sciences, 31-342 Kraków, Radzikowskiego 152, Poland
}

Received 3 October 2019

Accepted 23 May 2019

\begin{abstract}
The periodical nature of overbank sediment accumulation makes their detailed dating much more difficult than dating sediments in water reservoirs. To improve the commonly used dating with ${ }^{137} \mathrm{Cs}$, we combined this method with $\mathrm{Pu}$ isotopes and heavy metals in order to date sediments of the Chechło River (southern Poland), which was polluted by a lead-zinc mine. We analyzed ${ }^{137} \mathrm{Cs}$, Pu isotopes and heavy metal concentrations in three profiles of overbank sediments and in two profiles of subsidence basins in the lower river reach. The results indicate a lower accuracy and higher uncertainty of the overbank than the dating of reservoir sediments. The application of plutonium isotopes provided very important information validating caesium peaks or providing the principal information regarding horizons dated with heavy metals. The obtained dates give the earliest possible age of particular horizons with the actual sediment deposition delayed by several to a dozen years. This investigation shows that using plutonium radioisotopes can be a useful tool for dating, particularly of the youngest overbank sediments where numerous sedimentation gaps cause uncertainties in the application of other methods, e.g. radiocaesium and heavy metals.
\end{abstract}

Keywords: ${ }^{137} \mathrm{Cs}$, Pu isotopes, heavy metals, sediments, dating.

\section{INTRODUCTION}

Anthropogenic radionuclides $\left({ }^{137} \mathrm{Cs}\right.$ and $\mathrm{Pu}$ isotopes) originating from nuclear-weapons testing have been widely applied for dating sediments accumulated since the second half of the $20^{\text {th }}$ century. The ${ }^{137} \mathrm{Cs}$ is the most popular radionuclide used as a chronostratigraphic marker. Basing on the assumption of its negligible postdepositional mobility three dates can be obtained for sediment profiles. The time horizons are associated with the first radiocaesium detection in the global fallout of 1954, the maximum fallout in 1963-64 and with the Chernobyl accident in 1986 (UNSCEAR, 2000). The

Corresponding author: D. Ciszewski e-mail: ciszewski@geol.agh.edu.pl plutonium fallout history follows the pattern observed for ${ }^{137} \mathrm{Cs}$, and for this reason its isotopes, ${ }^{239} \mathrm{Pu}$ and ${ }^{240} \mathrm{Pu}$, which comprise mostly of $\mathrm{Pu}$ activity associated with the nuclear weapons fallout, mark the same time horizons (Hancock et al., 2011). Despite the total activity of plutonium being lower by $1-2$ orders of magnitude than ${ }^{137} \mathrm{Cs}$, it can be precisely determined using $\alpha$-particle spectroscopy because of the reduced counting time as well as the absence of a background and improved statistical precision of measurements (Everett at al., 2008). These advantages make $\mathrm{Pu}$ peaks suitable for validating the ${ }^{137} \mathrm{Cs}$ position in sediment profiles and in many circumstances they compensate the composed analytical procedure (Hancock et al., 2011; Tims et al., 2010). In the future, the application of plutonium isotopes as sediment chronomarkers with their much longer half-life than ${ }^{137} \mathrm{Cs}$ 
(24 110 years for ${ }^{239} \mathrm{Pu}$ and 6561 years for ${ }^{240} \mathrm{Pu}$ ) will potentially be of growing importance with the decrease of ${ }^{137}$ Cs detection.

In principle, sediment chronostratigraphy using heavy metals resembles dating with isotopes in the sense that it typically uses onset, maximum and emission cessation dates as markers of sediment horizons. Heavy metals can be used for sediment dating because the content of heavy metals in sediments accumulated during floods by a river is proportional to the degree of its pollution (Ciszewski, 2003). For this same reason, changes of heavy metals in vertical profiles of overbank or floodplain lake deposits mirror the variability of river pollution in the period of their deposition (Łokas et al., 2010a; Lintern et al., 2016). However, heavy metals originate from almost every kind of human activity, only the rapid changes in the discharge of metals to river systems can be utilized for dating time horizons (Hudson-Edwards et al., 1998). These changes are the most evident in areas of metal mining. In these areas, the distribution of particular elements in vertical profiles can be correlated to historical records of metal extraction and reworking (Ciszewski and Malik, 2004). Such a correlation is the most accurate in floodplain sections with a cm-scale accretion rate, which is constant over a longer time period (Ciszewski, 2003).

Under the assumption that there is a constant sediment supply rate over a period of isotope emission, more detailed chronologies can be constructed (Diaz-Assencio et al., 2014; Yao and Xue, 2016). These conditions, with sufficient rapid accumulation and constant sediment supply rates, commonly occur in water reservoirs like shelf seas, harbors or dam reservoirs (Frignani and Bellucci, 2004; Baeza et al., 2009), whereas the periodical nature of overbank sediment accumulation makes detailed dating of fluvial sediments much more difficult. Usually the sediment thickness left by consecutive floods is highly variable and deposition can be preceded by erosion of the previously accumulated sediment. The deposition rate is affected not only by the flood magnitude but also by the roughness of the floodplain surface, transported sediment load and flow velocity. Due to the extreme variability of the fluvial depositional environment, reconstruction of fluvial sediment deposition should be attempted using more than one dating method. The aim of the present investigations was to use the three dating methods: ${ }^{239,240} \mathrm{Pu},{ }^{137} \mathrm{Cs}$ and heavy metals to obtain a chronology of overbank sediments and deposits filling the subsidence depression in order to reconstruct pollution changes in a small valley of the Chechło River, which was polluted by a lead-zinc mine in southern Poland.

\section{STUDY SITE}

The Chechło River drains a limestone upland area of $110 \mathrm{~km}^{2}$ in southern Poland. The river is $23 \mathrm{~km}$ long and its average discharge in its lower course is equal to
$1.5 \mathrm{~m}^{3} \cdot \mathrm{s}^{-1}$. The river course can be divided into three well defined reaches. In the upper reach the river drains a Tertiary graben filled with fluvioglacial sands overgrown with a forest. The river channel crossing the forested area is weakly modified and the river waters are unpolluted. In the middle reach, the river flows across tectonically dislocated horst hills and receives the tributary formerly heavily polluted by the lead-zinc mine in Trzebinia. Alignment and incision of the channel in the middle river reach constricted the fluvial sediment deposition to the channel itself and the overbank accumulation of fine grained polluted deposits has not taken place as only the river valley widen in the lower river reach. The bottom of the valley in this reach increases up to $200-300 \mathrm{~m}$ and the channel gradient decreases. The meandering river reworks fluvioglacial sandy deposits. Coal extraction which takes place under the river bed resulted in the subsidence of the valley bottom over a $c a .500 \mathrm{~m}$ long river reach. The ground subsidence by about $1.5 \mathrm{~m}$ induced flooding of the whole depression. Presently, it is partially filled with sediments and overgrown with wetland plant communities. The open water surface takes up only about one third of the depression (Ciszewski, 2019).

Lead-zinc mining in Trzebinia started in 1968. The mine, which exploited karstified carboniferous rocks abundant in waters, discharged up to $0.5 \mathrm{~m}^{3} \cdot \mathrm{s}^{-1}$ of waters containing sediments polluted mainly with zinc, lead and cadmium into the Chechło River, and the river sediments were characterized in the 1990s by their very high pollution level (Ciszewski, 1997). In 1990s the mine excavated the largest amount of metal ores reaching $2.3 \mathrm{mln}$ tonnes. Since the beginning of the $21^{\text {st }}$ century ore extraction has declined. The process of mine closure started in 2006, but the mine was not closed until 2010.

\section{METHODS}

In order to possibly obtain a complete reconstruction of the river pollution chronology, sediments were taken from the floodplain and from the permanently flooded subsidence depression. Fine grained bottom sediments were sampled in two profiles (SBI and SBII) situated in ponded depressions on both riversides, a dozen or so metres from the channel using a Eijkelkamp multisampler (Fig. 1). Profile, SBI, was sampled from a depth of about $70 \mathrm{~cm}$ below the water table, whereas the water table at profile, SBII, was only $20 \mathrm{~cm}$ above the top of the profile. Both retrieved sediment profiles were $60 \mathrm{~cm}$ long. Overbank sediments were sampled from three bank outcrops (CI-CIII) with a $\varphi 80 \mathrm{~mm}$ stainless cylinder in distances growing downstream the subsidence basin. Two profiles, CII and CIII, were sampled to the average water table in the river at a depth of $1 \mathrm{~m}$, about $500 \mathrm{~m}$, and $250 \mathrm{~m}$ from the basin, respectively. The third profile, CI, at the lower perimeter of the subsided part of the valley, was sampled to a depth of about $60 \mathrm{~cm}$. 


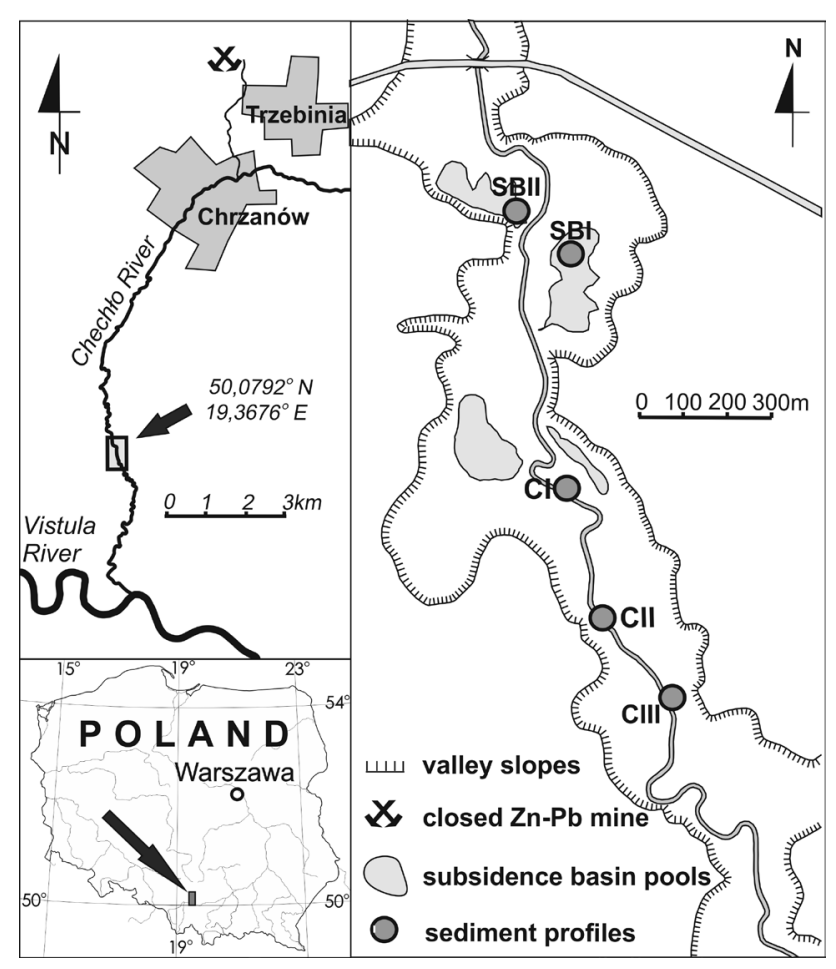

Fig. 1. Location of research area and sampling sites.

Sediment profiles from the bottom sediments were sectioned in intervals increasing with depth from 3 to $6 \mathrm{~cm}$, whereas the overbank sediments were sampled usually each $4-5 \mathrm{~cm}$ except the upper part of the profile CIII affected evidently by bioturbation and sampled each $10 \mathrm{~cm}$. The sampled sediments were divided into two subsamples. One part of the sample was wet sieved through a $0.063 \mathrm{~mm}$ sieve and digested with $\mathrm{HNO}_{3}$ according to EPA 3051 (USEPA, 1994) and then the $\mathrm{Zn}$ and $\mathrm{Pb}$ concentrations were determined using atomic absorption spectrometry. A standard quality control procedure was applied, including blind duplicates and reference materials with an error less than $10 \%$.

The other part of each sample was analysed using gamma $\left({ }^{137} \mathrm{Cs}\right)$ and alpha $\left({ }^{238} \mathrm{Pu},{ }^{239+240} \mathrm{Pu}\right)$ spectrometry in laboratory of the Institute of Nuclear Physics PAS in Krakow. For ${ }^{137} \mathrm{Cs}$ analyses, the samples were packed into $140 \mathrm{ml}$ polypropylene cylindrical containers and were measured using high-resolution gamma spectrometry with a planar HPGe (high-purity germanium) detector (with a relative efficiency of $10 \%$ ) with a composite foil window made of carbon fibre, which supports a capon foil covered with ultra-thin aluminium foil (homemade by the Institute of Nuclear Physics PAS Krakow workshop and electronics by Silena S.p.A.). The activities of ${ }^{137} \mathrm{Cs}$ were determined via the ${ }^{137 \mathrm{~m}} \mathrm{Ba}$ emission peak at $662 \mathrm{keV}$. The spectrometer was calibrated using a Mix Gamma source CBSS-2 produced by Inspectorate for Ionizing Radiation, Prague (Czech Republic), in form of the same vessel. Spectra were collected for 12-72 h, depending on the activity of the samples. The reference year for all measured activities of ${ }^{137} \mathrm{Cs}$ is 2017 . The cross-section of the sampling cylinder varied between 0.0063 and $0.0028 \mathrm{~m}^{-2}$, and these values were used in the inventory calculations. Radionuclide inventories in the sediment layers were calculated $\left(\mathrm{Bq} \cdot \mathrm{m}^{-2}\right)$ by summing the products of the radionuclides' activity concentrations $\left(\mathrm{Bq} \cdot \mathrm{kg}^{-1}\right)$ and appropriate surface dry masses $\left(\mathrm{kg} \cdot \mathrm{m}^{-2}\right)$. The total inventories in the sediment profiles were calculated by summing the inventory of all the layers for which activity concentrations were above MDC.

The contents of ${ }^{238} \mathrm{Pu},{ }^{239+240} \mathrm{Pu}$, as well as the silt content and losses on ignition (LOI) at $550^{\circ} \mathrm{C}$ were also analyzed in the subsamples. The activities of ${ }^{238} \mathrm{Pu}$ and ${ }^{239+240} \mathrm{Pu}$ were determined in about $5 \mathrm{~g}$ of the dried samples. The radiochemical procedure was started with a complete wet digestion using concentrated $\mathrm{HF}, \mathrm{HNO}_{3}$, $\mathrm{HCl}$ with the addition of a small amount of $\mathrm{H}_{3} \mathrm{BO}_{3}$. Finally, the sample solution was prepared in $1 \mathrm{M} \mathrm{HNO}_{3}$. The plutonium was separated by anion exchange in $8 \mathrm{M}$ $\mathrm{HNO}_{3}$ after adjustment of the oxidation state to $\mathrm{Pu}$ (IV) (LaRosa et al., 1992) using hydrazine and after a decomposition of hydrazine with an additional concentrated nitric acid using $\mathrm{NaNO}_{2}$ and $4 \mathrm{M} \mathrm{HNO}_{3}$. The final solution was set to $8 \mathrm{M} \mathrm{HNO}_{3}$. Separation of plutonium from the $8 \mathrm{M} \mathrm{HNO}_{3}$ solution was carried out using Dowex-1x8 anion exchange resin. The plutonium was removed from the anion-exchange column with a $0.1 \mathrm{M} \mathrm{HF}-0.1 \mathrm{M}$ $\mathrm{HCl}$ solution, after eluting thorium with $10 \mathrm{M} \mathrm{HCl}$ (Mróz et al., 2017; Łokas et al., 2013; Mietelski et al., 2008b). The plutonium alpha sources were prepared with the $\mathrm{NdF}_{3}$ microcoprecipitation method (Sill, 1987; Rao and Cooper, 1995). The chemical recoveries were determined using ${ }^{242} \mathrm{Pu}$ as the yield tracers. Details of the sequential radiochemical procedure used for the determination of the ${ }^{238} \mathrm{Pu}$ and ${ }^{239+240} \mathrm{Pu}$ activities have been described in previous publications (Lokas et al., 2010b, 2013). Measurements of the ${ }^{238} \mathrm{Pu}$ and ${ }^{239+240} \mathrm{Pu}$ activities were carried out using the Silena AlphaQuattro alpha spectrometer with Canberra PIPS (passivated implanted planar silicon) detectors and with an Alpha Duo spectrometer with Ortec detectors (each of $450 \mathrm{~mm}^{2}$ area). Typical measurements time were approximately 300,000 to 600,000 s.

Data quality was evaluated with the preparation and analysis of IAEA Reference Materials for radionuclides in soils (IAEA-385 and IAEA-444) as well as blanks using the same analytical procedures. The measured activity of ${ }^{239+240} \mathrm{Pu}(2.70 \pm 0.23 \mathrm{~Bq} / \mathrm{kg})$ was within the certified value $(2.89-3.00 \mathrm{~Bq} / \mathrm{kg})$; the activity of ${ }^{238} \mathrm{Pu}$ $(0.41 \pm 0.06 \mathrm{~Bq} / \mathrm{kg})$ was at the lower limit of the certified value $(0.42-0.48 \mathrm{~Bq} / \mathrm{kg})$. The activity of ${ }^{137} \mathrm{Cs}$ in IAEA444 was $67.5 \pm 6.6 \mathrm{~Bq} / \mathrm{kg}$, at the lower limit of the certified range $(67-70 \mathrm{~Bq} / \mathrm{kg})$. The reference year for all measured activities was 2017. Uncertainties lower than one sigma counting statistics are presented only. The laboratory of the Institute of Nuclear Physics PAS in Krakow has Polish state accreditation (ISO 17025) for gamma spectrometric measurements and $\mathrm{Pu}$ analyses. 


\section{RESULTS}

Stratigraphy of the collected sediments differs markedly between the two cores of the bottom reservoir sediments (SBI and SBII) and three overbank sediment profiles (CI, CII and CIII). The cores retrieved from the bottom sediments are characterized by their higher content of fine grained, silty particles $<0.063 \mathrm{~mm}$ (Fig. 2). These sediments also contain a high proportion of organic material (expressed as losses on ignition) which declines upward with an increased proportion of fine sand. This change manifests in appearance of mm-thick lamination in a dark-coloured matrix in the profiles top. The dark muds rest on a brighter basal, medium-grained sands with a low content of organics. The contrast between the basal and the upper sediment strata at a depth of about $0.5 \mathrm{~m}$ is striking in both bottom sediment profiles.

The overbank sediment profiles, CIII and CII, outcropped in the river banks are sandier than in reservoirs. The difference of their stratification from the reservoir deposits manifests in the presence of thicker and lighter sandy strata intercalated with dark organic silts a few $\mathrm{cm}$ thick. The top part of these profiles, particularly of CIII, comprise loose, finely laminated sands overgrown with a turf grass, whereas their bottom is compacted with blurred stratification. The sediments in the profile, CI, exhibit a higher proportion of silts in comparison to the profiles, CII and CIII (Fig. 2). These sediments are also not as homogenous as in reservoirs, but the intercalations of cm-thick sands developed towards the base and the basal dozen $\mathrm{cm}$ are composed mainly of brown-coloured sands.

The plutonium and caesium activity as well as the zinc and lead concentrations in the investigated sediments are given in Fig. 3. In each of the profiles there is at least one distinct peak of caesium; however, the maximum values differ by one order of magnitude. The highest value reaching almost $840 \pm 51 \mathrm{~Bq} \cdot \mathrm{kg}^{-1}$ was found in the basal part of the subsidence reservoir profile, SBI, at a depth of $56 \mathrm{~cm}$, while the lowest peak at $35 \pm 2 \mathrm{~Bq} \cdot \mathrm{kg}^{-1}$

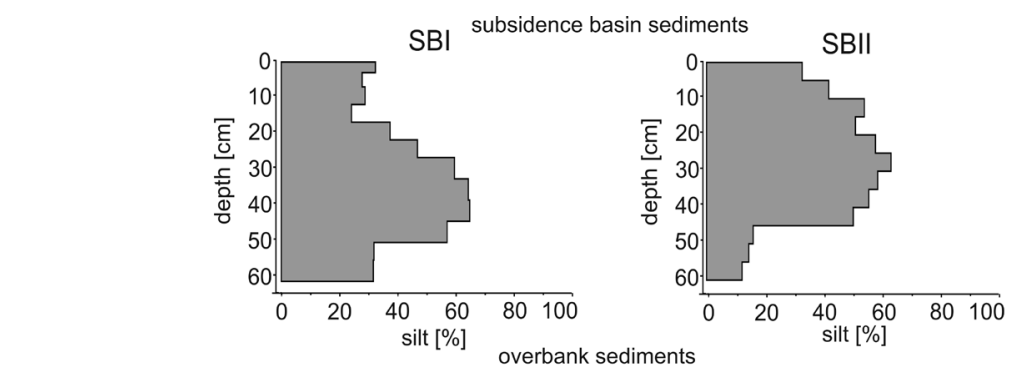

Fig. 2. Content of silt fraction and LOI in sampled sediment profiles.

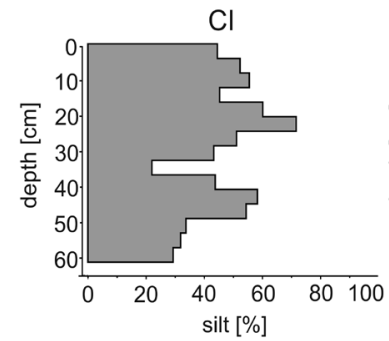

CII
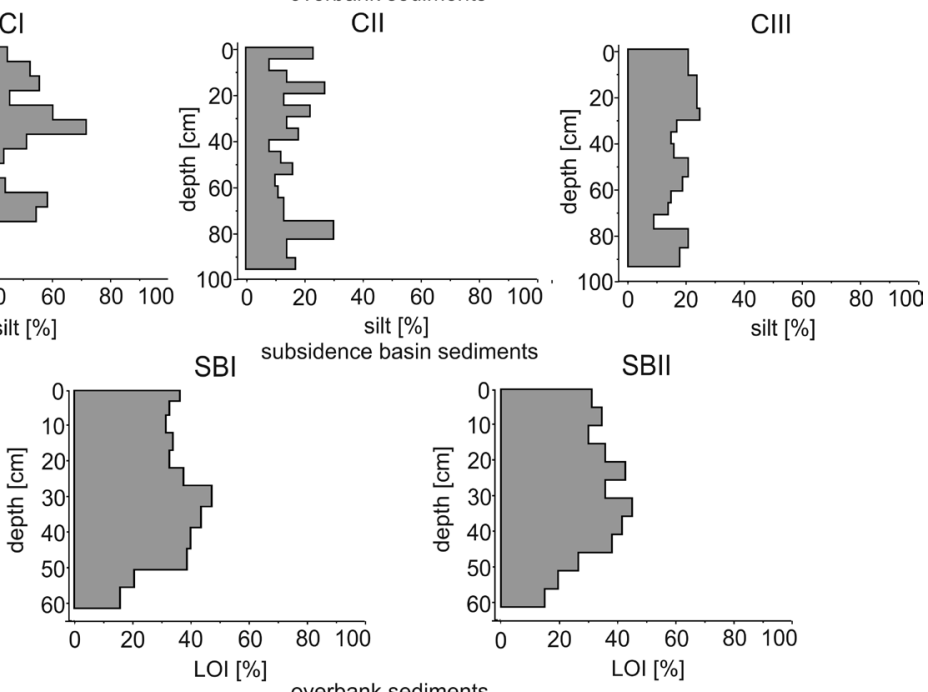

SBII
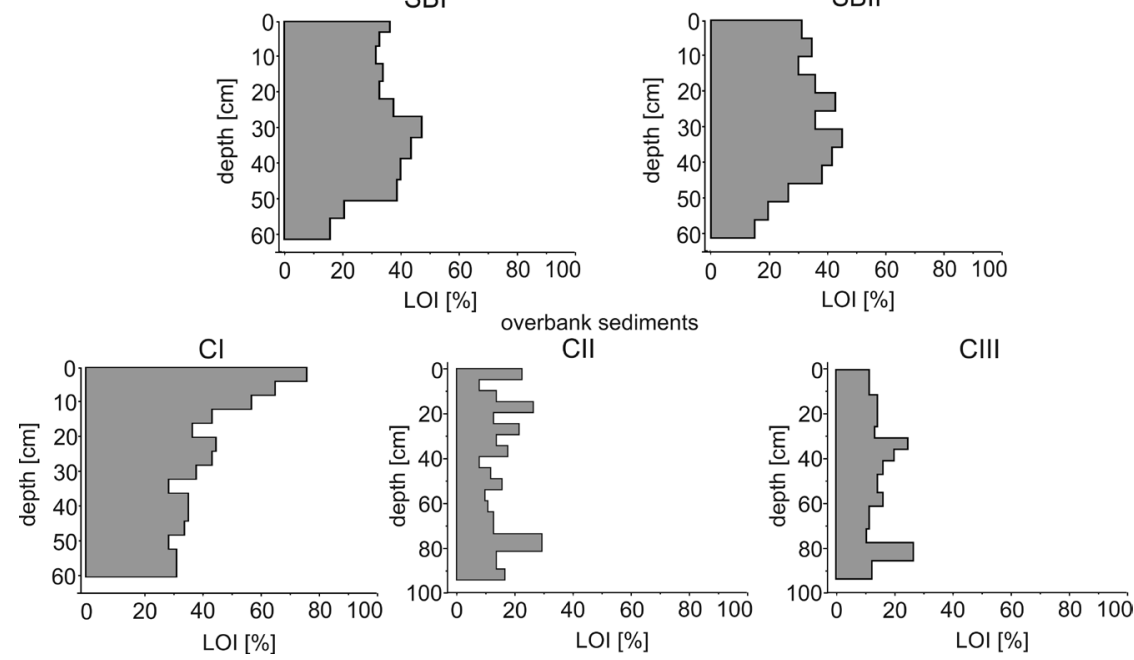

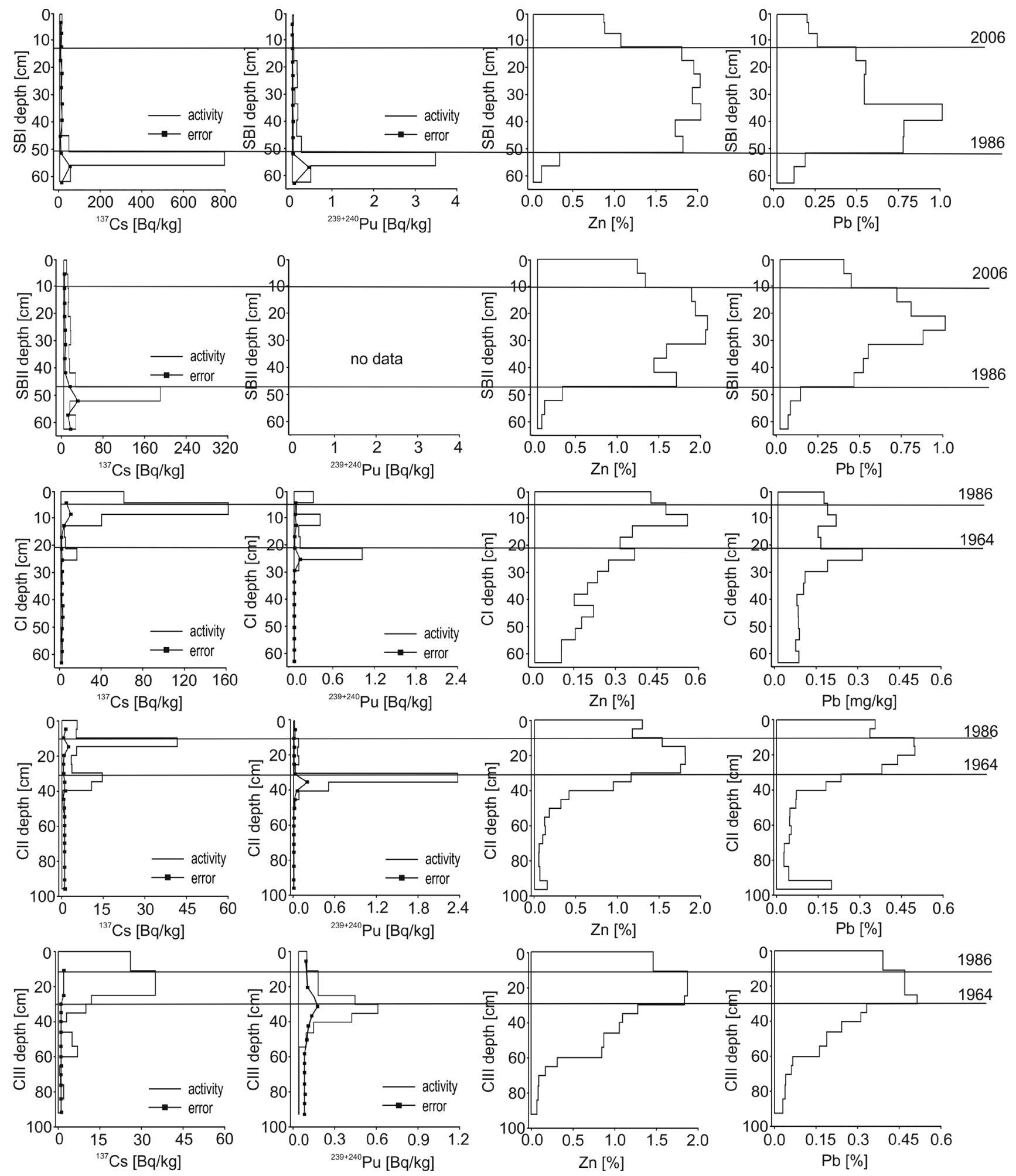

Fig. 3. Activity of ${ }^{137} \mathrm{Cs},{ }^{239,240} \mathrm{Pu}$ and concentrations of heavy metals in sampled sediment profiles.

was found in the top part of the overbank profile, CIII, at a depth of $25 \mathrm{~cm}$. The same regularity is also observed in the investigated ${ }^{239+240} \mathrm{Pu}$ activity with a maximum of $3.50 \pm 0.40 \mathrm{~Bq} \cdot \mathrm{kg}^{-1}$ at a depth of $50 \mathrm{~cm}$ in the SBI profile of the reservoir sediments and a minimum of $0.52 \pm 0.04$ $\mathrm{Bq} \cdot \mathrm{kg}^{-1}$ at a depth of about $36 \mathrm{~cm}$ in the overbank profile, CIII. In most of the profiles, the ${ }^{238} \mathrm{Pu}$ activity is below the minimum detection concentration (MDC) or very 
close to this value. In the profile, SBI, at a depth of $56 \mathrm{~cm}$ the activity of ${ }^{238} \mathrm{Pu}$ is $0.10 \pm 0.03 \mathrm{~Bq} \cdot \mathrm{kg}^{-1}$, and the activity ratio of ${ }^{238} \mathrm{Pu} /{ }^{239+240} \mathrm{Pu}$ for this sample is $0.028 \pm 0.009$. It is very close to the expected value for the global fallout, which is about 0.030 (UNSCEAR, 2000). But in the profile, CII, the activity of ${ }^{238} \mathrm{Pu}$ is $0.02 \pm 0.01 \mathrm{~Bq} \cdot \mathrm{kg}^{-1}$ at a depth of $20 \mathrm{~cm}$, and the activity ratio of ${ }^{238} \mathrm{Pu} /{ }^{239+240} \mathrm{Pu}$ is $0.34 \pm 0.08$. Table 1 presents radionuclides inventories for all the profiles. The inventories vary between $5700 \pm 630$ and $10130 \pm 930 \mathrm{~Bq} \cdot \mathrm{m}^{-2}$ for ${ }^{137} \mathrm{Cs}$, and between $59 \pm 7$ and $247 \pm 22 \mathrm{~Bq} \cdot \mathrm{m}^{-2}$ for ${ }^{239+240} \mathrm{Pu}$. The highest inventory for caesium is observed in the profile, $\mathrm{SBI}$, whereas the maximum ${ }^{239+240} \mathrm{Pu}$ inventory is observed in the profile, CII.

The investigated heavy metals display an extremely variable distribution pattern in all the sediment profiles (Fig. 3). Within every profile, lead concentrations differ by one order of magnitude, whereas zinc concentrations in most of the profiles differ even by two orders of magnitude. The largest peaks of both metals were found in the ponded basin, where zinc content reaches $c a .2 \%$ and lead content even exceeds $1 \%$ (of mass). The lowest pollution with these metals characterizes sediments of the profile, CI, situated just outside the subsidence basin, where the maximum zinc and lead content is equal to $0.5 \%$ and $0.3 \%$, respectively. The other two overbank sediment profiles are characterized with intermediate pollution. Concentrations of both metals exceed local geochemical background from several tens to several hundred times (Ciszewski, 1998) indicating strong river sediment pollution, particularly during the peak of mining.

Table 1. Average inventories $\left(\mathrm{Bq} \cdot \mathrm{m}^{-2}\right)$ for overbank sediments and reservoir sediments profiles.

\begin{tabular}{ccc}
\hline Profiles & $\begin{array}{c}{ }^{137} \text { Cs inventory } \\
\left(\mathbf{B q} \cdot \mathbf{m}^{-2}\right)\end{array}$ & $\begin{array}{c}239+240 \mathbf{P u} \text { inventory } \\
\left(\mathbf{B q} \cdot \mathbf{m}^{-2}\right)\end{array}$ \\
\hline $\mathrm{Cl}$ & $5480 \pm 580$ & $62 \pm 6$ \\
\hline $\mathrm{Cl}$ & $5700 \pm 630$ & $247 \pm 22$ \\
\hline $\mathrm{CII}$ & $7690 \pm 730$ & $71 \pm 6$ \\
\hline $\mathrm{SBI}$ & $10130 \pm 930$ & $59 \pm 7$ \\
\hline SBII & $5780 \pm 1000$ & $\mathrm{~nm}$ \\
\hline
\end{tabular}

$n m-$ not measured

\section{DISCUSSION}

\section{Chronostratigraphy of subsidence basin sediments}

The very high peaks of caesium and plutonium at the bottom of the profiles from reservoirs seem to be the most characteristic features of these sediments. Moreover, the position of these peaks agree with the rapid change in sediment stratigraphy suggesting their in situ occurrence. These peaks are associated with the valley floor, which subsided at the beginning of the 1990s. The process of land subsidence, which resulted from underground coal mining caused the ponding of water flowing in the river, a widespread process in mined areas (Zeng et al., 2017). In the investigated reach of the Chechło River valley, the bottom of the subsidence basin formed ultimately until the end of the 1990s, and the same age of the basal sediment strata is suggested by the high content of caesium and plutonium on the former floodplain surface. It results from a direct fallout of radioactive elements from the atmosphere and from an accumulation of these elements redistributed by surface runoff from the catchment during floods.

There are two main sources for these radionuclides in this region: the global radioactive atmospheric fallout and the Chernobyl accident. The mechanisms of release of Cs and $\mathrm{Pu}$ from Chernobyl are different. ${ }^{137} \mathrm{Cs}$ was released as a vapor and widespread all over the world, but $\mathrm{Pu}$ is not volatile and was only dispersed in the form of fuel particles. Previous works on plutonium in Poland (Mietelski and Wąs, 1995; Brudecki et al., 2009; Matisoff et al., 2011) revealed the presence of Chernobyl $\mathrm{Pu}$ in NE Poland. Pu can also be found in small amounts in the southern part of Poland (Mietelski et al., 2008a). Non-volatile elements like $\mathrm{Pu}$ can be transported on larger aerosols, "hot particles" (Cuddlhy et al., 1989; Devell et al., 1986). Because we can expect only small amounts of Chernobyl $\mathrm{Pu}$ in the investigated profiles of the Chechło catchment, the parallel occurrence of relatively high peaks of caesium and plutonium in the same strata of the reservoir sediments (SBI) seems to be a little surprising. It may be explained by the slow rate of overbank sediment accretion and an accumulation of radionuclides. Initially, the slow rate of the sediment accretion at both sampling points had been increasing over time as the channel became plugged with sediments and shallower favoring flooding already at lower discharges. Such regularity is suggested by an increased upward proportion of sands in both reservoir profiles. At the beginning of the pond formation and on the former channel floodplain, sediment accretion was slow, albeit persistent.

The peak of radiocaesium in the SBI profile is higher than on the floodplains of other European rivers and much higher than in lakes and estuaries of the southern hemisphere (Hancock et al., 2011; Sanders et al., 2017), whereas the peak of plutonium activity can be comparable to some extreme values from the Rhone River valley, which is affected by pollution from the Marcoule spentfuel reprocessing plant (Provansal et al., 2010). The very high value of radioisotopes can easily be explained by the topography of the sampling site, which is located outside the levee zone, in the centre of the undrained depression. Conditions favoring flood water stagnation at profile SBI are confirmed by the very high total inventory of ${ }^{137} \mathrm{Cs}$ $\left(10130 \mathrm{~Bq} \cdot \mathrm{m}^{-2}\right)$. This value is much higher than the value characteristic for global fallout (about $2000 \mathrm{~Bq} \cdot \mathrm{m}^{-2}$ ) after more than 50 years (UNSCEAR, 2000). The average 
deposition of the global fallout of ${ }^{239+240} \mathrm{Pu}$ for the territory in Poland is $58 \mathrm{~Bq} \cdot \mathrm{m}^{-2}$ (UNSCEAR, 2000) and this value is comparable to the ${ }^{239+240} \mathrm{Pu}$ total inventory for the SBI profile $\left(59 \pm 7 \mathrm{~Bq} \cdot \mathrm{m}^{-2}\right)$. The activity ratio of ${ }^{238} \mathrm{Pu} /{ }^{239+240} \mathrm{Pu}$ can be used to identify global and regional sources of these radionuclides. For the global fallout the ${ }^{238} \mathrm{Pu} /{ }^{239+240} \mathrm{Pu}$ activity ratio for Poland is approximately 0.030 (UNSCEAR, 2000), but for the Chernobyl fallout it is $\sim 0.50$ (Mietelski and Wąs, 1995). The activity ratio of ${ }^{238} \mathrm{Pu} /{ }^{239+240} \mathrm{Pu}$ for this layer indicates that the global fallout component is observed $(0.028 \pm 0.009)$.

The estimated weapons caesium deposition for Poland is $982 \mathrm{~Bq} \cdot \mathrm{m}^{-2}$, but the mean total (including Chernobyl) value for the ${ }^{137} \mathrm{Cs}$ inventory for Poland is $3770 \mathrm{~Bq} \cdot \mathrm{m}^{-2}$ (Stach, 1996) and this is a lower value than in the Upper Odra valley (SW Poland), which is equal to $5230 \mathrm{~Bq} \cdot \mathrm{m}^{-2}$ (Poręba and Bluszcz, 2007). The mean inventory value for the other regions of southern Poland, e.g. Opole and Katowice, is equal to $11240 \mathrm{~Bq} \cdot \mathrm{m}^{-2}$ and $6800 \mathrm{~Bq} \cdot \mathrm{m}^{-2}$, respectively (Stach, 1996), but the contribution of ${ }^{137} \mathrm{Cs}$ from the Chernobyl fallout is about $80 \%$ of the total ${ }^{137} \mathrm{Cs}$ fallout. This suggests that in the profiles from the subsidence basin Chernobyl Cs is also prevalent and dates the horizon of the former floodplain surface.

In Fig. 3 the rapid rise of zinc and lead content in the profiles from reservoirs is concordant with the beginning of stagnant sedimentary conditions and has been marked as the horizon 1986. The observed change in metal concentrations results from the accumulation of highly polluted deposits during the peak of mining in the $2^{\text {nd }}$ half of the 1990s. The peak of mining followed by a slow decrease in metal extraction at the break of the $20^{\text {th }}$ century is best mirrored in the profile, SBII, which is situated close to the river channel in a part of the basin connected with the river via a secondary channel. The change is not observed in the profile, SBI, from the centre of the depression probably because part of the deposits transported by flood waters is trapped by a zone of dense macrophytes overgrowing the shoreline of the depression. The simultaneous drop of lead and zinc concentrations in both profiles at a depth of 10-12 $\mathrm{cm}$ may be associated with the beginning of the mine closure in 2006 when the drop of metal extraction was accompanied with a rapid decrease of mine waters discharged to the river. Even though the mine was eventually closed down in 2010, we may expect that this drop of channel pollution could have appeared as early as 2006 and the data indicated in Fig. 3 terminates its earliest possible supervention, so the age of the sediments should be interpreted as "the older than" but not of the exact dates indicated for particular horizons. In effect, the declining rate of river sediment pollution is related mainly to the flood frequency and magnitude and the largest floods are the most efficient in inchannel sediment mixing and downstream transport (Ciszewski, 2001). In the case of the Chechło River, the rapid drop of zinc and lead concentrations, even by one order of magnitude, was evidenced in channel sediments less than 10 years after the mine closed down leading also to a drop in their content in sediments filling the offchannel reservoirs formed soon after the beginning of the mine closure process (Ciszewski, 2019). The drop of metals in the sediments in response to the closure of the mine is always followed by a longer period of slower decline in sediment pollution because the metals are commonly associated not only with the channel sediments but also because the overbank sediments constitute an important secondary pollution source (Žák et al., 2009; Foulds et al., 2013). In river systems with long active mining, metals dispersed in catchment soils are slowly eroded by surface runoff maintaining a raised metal pollution in alluvia even for more than one hundred years (Pirrie et al., 1997). This is also the case for the Chechło catchment, in which persistent pollution is predicted with the metals content well above the natural background, for many years to come (Ciszewski, 2019). For this reason, in the top of the overbank profiles a remarkable drop of zinc and lead concentrations is not present (Fig. 3).

\section{Chronostratigraphy of overbank sediments}

The relatively poor resolution of the obtained top sediment strata of the overbank sediments results from a low rate of sediment accretion, loose character of fine sands and their possible translocation within the root zone. For this reason, changes in the content of both metals in the surface sediment samples that were observed in all overbank profiles were not suitable for delimitation of postmining horizon, and the reconstruction of the environmental history was based mainly on caesium and plutonium radioisotopes in overbank sediments.

Basing on two caesium peaks in all the overbank profiles, we used the upper one as a marker of the year 1986. The majority of ${ }^{137} \mathrm{Cs}$ in these profiles was found in the upper $15-40 \mathrm{~cm}$ of strata. In the CIII and CII profiles the subsurface maximum activity of ${ }^{137} \mathrm{Cs}$ produced by the Chernobyl accident occurs at depths of 10-12 cm, whereas the subsurface maximum activity of ${ }^{239+240} \mathrm{Pu}$ generated from the bomb testing fallout in 1964 is at depths of $30 \mathrm{~cm}$ and $35 \mathrm{~cm}$ in profiles CIII and CII, respectively. In all of these profiles the activity of ${ }^{239+240} \mathrm{Pu}$ was higher than in other river sediments of southern Poland (Komosa, 1999). The total inventory of ${ }^{239+240} \mathrm{Pu}$ for profiles CI, CIII are very close to the expected value for the global fallout, but for profile, CII, it is much higher $\left(247 \mathrm{~Bq} / \mathrm{m}^{2}\right)$. The maximum value of ${ }^{239+240} \mathrm{Pu}$ in profile, CII, is at a depth of $35 \mathrm{~cm}$ and this maximum is related to the global fallout deposition. The lower peak of ${ }^{239+240} \mathrm{Pu}$ is found at a depth of $20 \mathrm{~cm}$ and the activity ratio of ${ }^{238} \mathrm{Pu} /{ }^{239+240} \mathrm{Pu}$ is $0.34 \pm 0.08$ and it might be related to the Chernobyl Pu origin (most likely in the form of hot particles), but this activity is several times lower than for the global fallout. Similar results were observed in the Tatra Mountains, where excess ${ }^{238} \mathrm{Pu}$ activity was found in soil samples (Mietelski et al., 2008a). The radioisotope peaks 
indicate that the horizon at a depth of $10-12 \mathrm{~cm}$ in profiles, CII and CIII, can be assigned to a date after 1986. Dating of this horizon in all overbank profiles is based mainly on the position of upper cesium peaks and is not confirmed by a significant increase in activity of plutonium isotopes. The data of the horizon 1964 is obtained from both the ${ }^{137} \mathrm{Cs}$ and ${ }^{239+240} \mathrm{Pu}$ peaks and agree well with the distinct rise of zinc and lead content just above this depth in the profile, CII, and could be associated with the construction of the mine in the second half of the 1960s. Even though the construction of the mine was finished in 1968, mine waters were discharged as early as a few years earlier and the data of this level indicates high river pollution with these metals since the very beginning of the mine's operation. This is the first information regarding metal pollution on this ungauged and never monitored river. The very high river pollution during the whole period of the mine's operation seems to be confirmed also by similar peaks of zinc and lead in the profile, CIII. In both profiles, the thickness of the sediment strata associated with the mine's operation is equal to about $20 \mathrm{~cm}$. Considering that the mine was operational for 40 years we can roughly estimate the average rate of annual sediment accretion during that period in CII and CIII to be $0.5 \mathrm{~cm}$.

The profile, CI, differs markedly from the other overbank profiles in respect to sediment stratigraphy and also to a much lower content of metals. The peaks of zinc and lead are even three times lower, and levels with a drop or sharp increase are not noticeable in their distribution pattern. Two peaks of caesium at $4-8 \mathrm{~cm}$ and $20-24 \mathrm{~cm}$ and one peak of plutonium at the same depth of $20-24 \mathrm{~cm}$ are the only time markers. The couple of lower peaks helped determine a time horizon of 1964 as the earliest possible deposition time of the mining era sediments, whereas the distinct upper peak of caesium dated horizon of 1986. The thickness of these sediments constrained by the two dates, although comparable to the other overbank profiles, is a little bit smaller and is equal to $15 \mathrm{~cm}$. These differences are related to the location of this profile at a lower floodplain level. Moreover, during the peak of mining this profile was situated not at the river bank but several metres farther as the channel shifted over the $2^{\text {nd }}$ half of the $20^{\text {th }}$ century. The distance from the channel is known to be a factor controlling the sediment accretion rate (Łokas et al., 2010a) and could explain the determined lower sediment thickness.

The high accretion rate of reservoir sediments, exceeding on average 2-3 times the accretion of mining era overbank sediments, was beneficial for accurately dating the recent 30 year-long period of sedimentation. In turn, the relatively slow and periodical nature of overbank flood deposition with a significant multi-annual delay resulted in sedimentation gaps and difficulties in building environmental reconstruction based on the overbank sediments. Nevertheless, by considering several profiles from different topographic situations, we eliminated some uncertainties due to a lack of some peaks of radioisotopes or blurred original zinc and lead concentration horizons. A similar thickness of the mining-era sediments, in particular fluvial sub-environments, confirmed the correctness of dating and the reconstructed most recent pollution history did not suffer from a poorer sample resolution in the top of the overbank profiles.

The accuracy of the obtained fluvial sediment dating could also be affected to some extent by post-depositional mobilization. Generally, plutonium and caesium are considered to be good time markers because they strongly bind to mineral or organic particles and remain immobile over a significant time period (Tims et al., 2010; Everett et al., 2008). Heavy metals like zinc and lead can be more easily remobilized particularly under frequent changes of the water table as well as between oxic and anoxic conditions and migrate downward in overbank profiles (Rinklebe and Du Laing, 2011; Ciszewski et al., 2008). In most of the presented profiles distinct radioisotope peaks correspond reasonably with the peaks of metals; however, the long tails of metals below the peaks in the CIII and CII profiles and the blurred peaks in CI exhibit the important role of post-depositional metal migration processes in overbank sediments. Such processes are negligible in reservoir sediments with stable anoxic conditions hampering organic matter degradation, which is able to affect the fate and transport of radionuclides and heavy metals (Sanders et al., 2017; Kalbitz and Wenrich, 1998).

\section{CONCLUSIONS}

Dating of overbank and reservoir sediments helped to reconstruct the history of pollution in the Chechło River by the lead and zinc mine. However, the obtained dates give the earliest possible age of particular horizons with the actual sediment deposition delayed by several to a dozen years. The dating indicates a very high river pollution with zinc and lead over the entire period of the mine's operation with a rise possibly to occur simultaneously with the maximum ore extraction in the second half of the 1990s.

Gaps in overbank sedimentary sequences preclude extending of the sedimentation rate $0.5 \mathrm{~cm} /$ year obtained for the mining period on longer sections of these profiles. Instead we may compare this sedimentation rate with that observed in both subsidence reservoirs in a similar period of time, which is about $2-3$ times higher.

The results indicate a lower accuracy and higher uncertainty of the overbank than reservoir sediment dating.

The application of plutonium isotopes provided very important information validating caesium peaks or, as in one profile, providing the only reliable information regarding horizon dating. This example has shown that plutonium radioisotopes can be a useful tool for dating particularly the youngest overbank sediments where numerous sedimentation gaps cause uncertainties in the application of other methods, e.g. radiocaesium. 


\section{ACKNOWLEDGEMENTS}

Research was funded by National Science Center, Poland grant no. 2014/15/B/ST10/03862.

\section{REFERENCES}

Baeza A, Guillen J, Salamanca MA, Rodriguez A and Ager FJ, 2009. Radiological and multi-element analysis of sediments from the Proserpina reservoir (Spain) dating from Roman times. Journal of Environmental Radioactivity 100: 866-874, DOI 10.1016/j.jenvrad.2009.06.020.

Brudecki K, Suwaj J and Mietelski JW, 2009. Plutonium and ${ }^{137} \mathrm{Cs}$ in forest litter: an approximate map of plutonium from Chernobyl deposition in North-eastern and Eastern Poland. Nukleonika 54: 199-209.

Ciszewski D, 1997. Source of pollution as a factor controlling dispersal of heavy metals in river bottom sediments. Environmental Geology 29: 50-57.

Ciszewski D, 1998. Channel processes as a factor controlling accumulation of heavy metals in river bottom sediments: consequences for pollution monitoring (Upper Silesia, Poland). Environmental Geology 36: 45-54, DOI 10.1007/s002540050319.

Ciszewski D, 2001. Flood-related changes in heavy metal concentrations within sediments of the Biała Przemsza River. Geomorphology 40: 205-218, DOI 10.1016/S0169-555X(01)00044-7.

Ciszewski D, 2003. Heavy metals in vertical profiles of the middle Odra River overbank sediments: Evidence for pollution changes. Water, Air and Soil Pollution 143: 81-98, DOI 10.1023/A:1022825103974.

Ciszewski D, Czajka A and Blazej S, 2008. Rapid migration of heavy metals and (137)Cs in alluvial sediments, Upper Odra River valley, Poland. Environmental Geology 55: 1577-1586, DOI 10.1007/s00254-007-1108-9.

Ciszewski D and Malik I, 2004. The use of heavy metal concentrations and dendrochronology in the reconstruction of sediment accumulation, Mala Panew River Valley, southern Poland. Geomorphology 58: 161-174, DOI 10.1016/S0169-555X(03)00230-7.

Ciszewski D, 2019. The past and prognosis of mining cessation impact on river sediment pollution. Journal of Soils and Sediments 19: 393-402, DOI 10.1007/s11368-018-2015-2.

Cuddihy RG, Finch GL, Newton GJ, Hahn FF, Mewhinney JA, Rothenberg SJ and Powers DA, 1989. Characteristics of radioactive particles released from the Chernobyl nuclear reactor. Environmental Science \& Technology, 23(1): 89-95, DOI 10.1021/es00178a011.

Devell L, Tovedal H, Bergström U, Appelgren A, Chyssler J and Andersson L, 1986. Initial observations of fallout from the reactor accident at Chernobyl. Nature 321(6067): 192-193, DOI 10.1038/321192a0.

Diaz-Asencio M, Sanchez-Cabeza JA, Bolanos-Alvarez Y, RuizFernandez AC, Gomez-Batista $\mathrm{M}$, Morabito $\mathrm{R}$ and AlonsoHernandez C, 2014. One century of sedimentation and Hg pollution at the mouth of the Sagua la Grande River (Cuba). Ciencias Marinas 40: 321-337, DOI 10.7773/cm.v40i4.2472.

Everettt SE, Tims SG, Hancock GJ, Bartley R and Fifield LK, 2008. Comparison of $\mathrm{Pu}$ and ${ }^{137} \mathrm{Cs}$ as tracers of soil and sediment transport in a terrestrial environment. Journal of Environmental Radioactivity 99: 383-393, DOI 10.1016/j.jenvrad.2007.10.019.

Foulds SA, Macklin MG and Brewer PA, 2013. Agro-industrial alluvium in the Swale catchment, northern England, as an event marker for the Antropocene. Holocene 23: 587-602, DOI $10.1177 / 0959683612465445$.

Frignani M and Bellucci LG, 2004. Heavy metals in marine coastal sediments: Assessing sources, fluxes, history and trends. Annali di Chimica 94: 479-486, DOI 10.1002/adic.200490061.

Hancock GJ, Leslie C, Everett SE, Tims SG, Brunskill GJ and Haese R, 2011. Plutonium as a chronomarker in Australian and New Zealand sediments: a comparison with ${ }^{137} \mathrm{Cs}$. Journal of Environmen- tal Radioactivity 102: 919-929,

DOI

10.1016/j.jenvrad.2009.09.008.

Hudson-Edwards KA, Macklin MG, Curtis CD and Vaughan DJ, 1998. Chemical remobilization of contaminant metals within floodplain sediments in an incising river system: implications for dating and chemostratigraphy. Earth Surface Processes and Landforms 23: 671-684, DOI 10.1002/(SICI)1096-9837(199808)23:8<671::AIDESP871>3.0.CO;2-R.

Kalbitz K and Wenrich R, 1998. Mobilization of heavy metals and arsenic in polluted wetland soils and its dependence on dissolved organic matter. Science of the Total Environment 209: 27-39, DOI 10.1016/S0048-9697(97)00302-1.

Komosa A, 1999. River sediment contamination with plutonium isotopes and heavy metals in Lublin agglomeration (Poland). Polish Journal of Environmental Studies 8: 155-160.

LaRosa JJ, Cooper EL, Ghods-Esphahani A, Jansta V, Makarewicz M, Shawky S and Vajda N, 1992. Radiochemical methods used by the IAEA's laboratories at Seibersdorf for the determination of ${ }^{90} \mathrm{Sr}$, ${ }^{144} \mathrm{Ce}$ and $\mathrm{Pu}$ radionuclides in environmental samples collected for the international Chernobyl project. Journal of Environmental Radioactivity 17(2-3): 183-209, DOI 10.1016/0265-931X(92)90025-O.

Lintern A, Leahy PJ, Heijnis H, Zawadzki A, Gadd P, Jacobsen G, Deletic A and Mccarthy DT, 2016. Identifying heavy metal levels in historical flood water deposits using sediment cores. Water Research 105: 34-46, DOI 10.1016/j.watres.2016.08.041.

Łokas E, Wachniew P, Ciszewski D, Owczarek P and Chau ND, 2010a. Simultaneous Use of Trace metals, ${ }^{210} \mathrm{~Pb}$ and ${ }^{137} \mathrm{Cs}$ in floodplain sediments of a lowland river as indicators of anthropogenic impacts. Water, Air and Soil Pollution 207: 57-71, DOI 10.1007/s11270-009-0119-4.

Łokas E, Mietelski JW, Kleszcz K and Tomankiewicz E, 2010b. A sequential procedure for determining ${ }^{238} \mathrm{Pu},{ }^{239+240} \mathrm{Pu},{ }^{241} \mathrm{Am},{ }^{90} \mathrm{Sr}$, $\mathrm{U}$ and $\mathrm{Th}$ activities in soils and peats from Spitsbergen. Nukleonika 55: 195-199.

Łokas E, Mietelski JW, Ketterer ME, Kleszcz K, Wachniew P, Michalska S and Miecznik M, 2013. Sources and vertical distribution of ${ }^{137} \mathrm{Cs},{ }^{238} \mathrm{Pu},{ }^{239+240} \mathrm{Pu}$ and ${ }^{241} \mathrm{Am}$ in peat profiles from southwest Spitsbergen. Applied Geochemistry 28: 100-108, DOI 10.1016/j.apgeochem.2012.10.027.

Matisoff G, Ketterer M, Rosén K, Mietelski JW, Vitko LF, Persson H and Lokas E, 2011. Downward migration of Chernobyl-derived radionuclides in soils in Poland and Sweden. Applied Geochemistry 26 (1): 105-115, DOI 10.1016/j.apgeochem.2010.11.007.

Mietelski JW and Wąs B, 1995. Plutonium from Chernobyl in Poland. Applied Radiation and Isotopes. 46: 1203-1211, DOI 10.1016/0969-8043(95)00162-7.

Mietelski JW, Kubica B, Gaca P, Tomankiewicz E, Błażej S, TutejaKrysa M, Stobiński M, 2008a. ${ }^{238} \mathrm{Pu},{ }^{239+}{ }^{240} \mathrm{Pu},{ }^{241} \mathrm{Am},{ }^{90} \mathrm{Sr}$ and ${ }^{137} \mathrm{Cs}$ in mountain soil samples from the Tatra National Park (Poland). Journal of Radioanalytical and Nuclear Chemistry 275: 523-533, DOI 10.1007/s10967-007-7026-1.

Mietelski JW, Mirocha S and Bogacz J, 2008b. Plutonium and gamma emitters in the northeastern part of Bory Tucholskie (Poland). Nukleonika 53: 17-25.

Mróz T, Łokas E, Kocurek J and Gąsiorek M, 2017. Atmospheric fallout radionuclides in peatland from Southern Poland. Journal of Environmental Radioactivity 175-176: 25-33, DOI 10.1016/j.jenvrad.2017.04.012.

Pirrie D, Camm GS, Sear LG and Hughes SH, 1997. Mineralogical and geochemical signature of mine waste contamination, Tresilian River, Fal Estuary, Cornwall, UK. Environmental Geology 29: 5865, DOI 10.1007/s002540050104.

Poręba G and Bluszcz A, 2007. Determination of the initial ${ }^{137} \mathrm{Cs}$ fallout on the areas contaminated by Chernobyl fallout. Geochronometria 26: 35-38, DOI 10.2478/v10003-007-0009-y.

Provansal M, Villet J, Eyrolle F, Raccasi G, Gurriaran R, Antonelli C, 2010. High-resolution evaluation of recent bank accretion rate of the managed Rhone: a case study by multi-proxy approach. Geomorphology 117: 287-297, DOI 10.1016/j.geomorph.2009.01.017.

Rao RR and Cooper EL, 1995. Separation of low levels of actinides by selective oxidation/reduction and co-precipitation with neodymium 
fluoride. Journal of Radioanalytical and Nuclear Chemistry 197: 133-148, DOI 10.1007/BF02040226.

Rinklebe J and Du Laing G, 2011. Factors controlling the dynamics of trace metals in frequently flooded soils, p. 245-270. In: Selim HM [ed.], Dynamics and Bioavailability of heavy metals in the root zone, CRC Press.

Sanders LM, Enrich-Prast A, Taffs KH, Stokes TD and Sanders Ch, 2017. ${ }^{240+239} \mathrm{Pu}$ depositional signatures as a viable geochronological tool in the Amazon Basin. Geochronometria 44: 142-149, DOI 10.1515/geochr-2015-0068.

Sill CW, 1987. Precipitation of actinides as fluorides or hydroxides for high resolution alpha spectrometry. Nuclear Chemistry and Waste Management 7: 201-215.

Stach A, 1996. Możliwosci i ograniczenia zastosowania cezu-137 do badan erozji gleb na obszarze Polski. Instytut Uprawy, Nawożenia $i$ Gleboznawstwa w Pulawach. Seria K 2.11: 203-226.

Tims SG, Everett SE, Fifield LK, Hancock GJ and Bartley R, 2010. Plutonium as a tracer of soil and sediment movement in the Her- bert River, Australia. Nuclear Instruments and Methods in Physics Research B, 268: 1150-1154, DOI 10.1016/j.nimb.2009.10.121.

UNSCEAR, 2000. Sources and effects of ionizing radiation, vol 1. United Nations Scientific Committee on the Effects of Atomic Radiation, New York, $245 \mathrm{pp}$.

USEPA, 1994. Method 3051: Microwave assisted acid digestion of sediments, sludges, soils, and oils. Revision 0. USEPA.

Yao SC and Xue X, 2016. Sediment records of the metal pollution at Chihu Lake near a copper mine at the middle Yangtze River in China. Journal of Limnology 75: 121-134, DOI 10.4081/jlimnol.2015.1241.

Žák K, Rohovec J and Navrátil T, 2009. Fluxes of heavy metals from a highly polluted watershed during flood events: a case study of the Litavka River, Czech Republic. Water, Air and Soil Pollution 203: 343-358, DOI 10.1007/s11270-009-0017-9.

Zeng F, Wu K, He Q, Diao X and Li L, 2017. Model establishment for ponding in coal mining subsidence areas and its prediction: case study of Northern Jining, China. Geotechnical and Geological Engineering 35: 83-89, DOI 10.1007/s10706-016-0086-7. 